\title{
Dialogic listening: how music may help us become better philosophers
}

Pablo Muruzábal Lamberti

Candidato a doctor de la Universidad de Amsterdam

Universidad de Amsterdam - Holanda p.d.c.muruzaballamberti@uva.nl https://orcid.org/0000-0002-0149-2284

\section{Artículo de investigación}

Recepción: 15 de diciembre de 2018 Aprobación: 29 de enero de 2019 https://doi.org/10.19053/22160159.v10.n23.2019.9733

\section{Abstract}

This paper is about dialogic listening as a precondition for meaningful engagement in Socratic dialogues and for music. In order to arrive at a better understanding of what constitutes dialogic listening in the context of educational philosophical dialogues, I first shed light on the practice of philosophy teaching based on Nelson \& Heckmann's neo-Socratic paradigm and link this practice to Plato's dialogues. I then argue that the activity of listening to an interlocutor during Socratic dialogues on the one hand, and listening to music on the other, may in both cases be understood as a precondition for the process of engagement and, consequently, the co-creation of meaning as a central objective to the philosophical practice. I show this by discussing both Buber and Gadamer, combining their insights into three interrelated features of dialogic listening: 1) openness, 2) reciprocity, and 3) awareness, which apply to both philosophical dialogues and music. Ultimately, I attempt to make a case for the complementary application of music in the philosophical educational practice.

Keywords: listening, dialogue, music, philosophy, education 


\section{Escucha dialógica: cómo la música nos puede ayudar a ser mejores filósofos}

\section{Resumen}

En este artículo se habla acerca de la escucha dialógica como requisito tanto para la participación significativa en los diálogos socráticos educativos como para la música. Con el fin de entender mejor la definición de escucha dialógica en los diálogos filosóficos educativos, hablo sobre la práctica de la enseñanza de filosofía basada en el paradigma neosocrático de Nelson y Heckmann y la relaciono con los diálogos de Platón. Luego, planteo que escuchar a un interlocutor durante diálogos socráticos y escuchar música pueden ser un requisito para el involucramiento y, en consecuencia, para la co-creación de sentido como objetivo central de la práctica filosófica. Para tal fin, recurro a Buber y Gadamer y combino sus puntos de vista en tres elementos de la escucha dialógica que se interrelacionan: 1) apertura, 2) reciprocidad y 3) conciencia del otro, los cuales aplican tanto a los diálogos filosóficos como a la música. Por último, defiendo el uso complementario de la música en la práctica educativa de la filosofía.

Palabras clave: escuchar, diálogo, música, filosofía, educación

\section{l'écoute dialogique : comment la musique peut nous aider à être de meilleurs philosophes}

\section{Résumé}

Dans cet article, je parle de l'écoute dialogique en tant que condition aussi bien pour la participation significative aux dialogues socratiques dans le milieu éducatif que pour la musique. Afin de mieux comprendre la définition d'écoute dialogique dans les dialogues philosophiques éducatifs, je m'adresse sur la pratique de l'enseignement de la philosophie fondée 
sur le paradigme néo-socratique de Nelson et Heckmann et je fais un rapprochement avec les dialogues de Platon. Ensuite, j'affirme que le fait d'écouter un interlocuteur lors des dialogues socratiques et le fait d'écouter de la musique pourraient être une condition pour participer et, par conséquent, pour co-créer du sens comme l'objectif principal de la pratique philosophique. Dans ce but, je m'appuie sur les points de vue de Buber et Gadamer, en les combinant avec trois éléments de l'écoute dialogique qui sont interconnectés : 1) ouverture, 2) réciprocité, et 3) conscience d'autrui ; lesquels peuvent être appliqués aussi bien aux dialogues philosophiques qu'à la musique. Enfin, je défends l'usage complémentaire de la musique dans la pratique éducative de la philosophie.

Mots-clés : l'écoute, le dialogue, la musique, la philosophie, l'éducation

\section{Escuta dialógica: como a música pode nos ajudar a ser melhores filósofos}

\section{Resumo}

Neste artigo, falo sobre a escuta dialógica como requisito tanto para a participação significativa nos diálogos socráticos educativos e como para a música. Para entender melhor a definição de escuta dialógica nos diálogos filosóficos educativos, falo sobre a prática do ensino da filosofia baseada no paradigma neo-socrático de Nelson e Heckmann e a relaciono com os diálogos de Platão. Logo proponho que escutar um interlocutor durante os diálogos socráticos e escutar música podem ser um requisito para o envolvimento e, em consequência, para a co-criação de sentido como objetivo central da prática filosófica. Para esse fim, recorro a Buber e Gadamer, combinando seus pontos de vista em três elementos de escuta dialógica que se inter-relacionam: 1) atitude aberta, 2) reciprocidade e 3) consciência do outro; os quais se aplicam tanto aos diálogos filosóficos como à música. Finalmente, defendo o uso complementário da música na prática educativa da filosofia.

Palavras-chave: ouvir, dialogar, música, filosofia, educação 


\section{Introduction: Plato and the neo-Socratic paradigm}

As one of the founding figures of Socratic education, Leonard Nelson (1882-1927) put it: "the Socratic method is the art of teaching not philosophy but philosophizing, the art not of teaching about philosophers but of making philosophers of the students" (Nelson, 1949, p. 18). This seems to make sense: teaching primary school children about philosophers and their theories is not likely to be very fruitful just yet. Philosophizing as a practice, however, is something that aligns much more with the natural inquisitiveness of primary school children. After all, what is practiced is wondering about the world by cooperatively reflecting on philosophical issues. Indeed, "wonder is the only beginning of philosophy" (Plato, Theaetetus, section 155d; Schinkel 2017, 2018).

The Socratic practice as fostered by Nelson \& Heckmann, also referred to as the neo-Socratic paradigm, offers a way to philosophize. Although this practice presupposes and promotes certain crafts, it is not a technique. Rather, it implies an attentive and thorough investigation of thoughts, attitudes and behaviours, and departs from an intention to collaborate philosophically. (Raupach-Strey, 2012)

The case of Plato's famous dialogue Menon and the comparison between Socrates and a torpedo fish, which numbs anything it touches, serves as a good example of the process of co-creating meaning, inherent to the educational practice. Socrates responds to Menon's allegation as follows:

As for me, if the torpedo is torpid itself while causing others to be torpid, I am like it, but not otherwise. For it is not from any sureness in myself that I cause others to doubt: it is from being in more doubt than anyone else that I cause doubt in others. So now, for my part, I have no idea what virtue is, whilst you, though perhaps you may have known before you came in touch with me, are now as good as ignorant of it also. But nonetheless I am willing to join you in examining it and inquiring into its nature. (Plato, Menon, section 8oa-d)

Especially this willingness to cooperate-presupposed in the notion of dialogue-instead of lecturing, is what makes Socrates one of the prime embodiments of the dialogic philosophical practice in today's educational contexts. 
As the name suggests, the neo-Socratic paradigm is heavily influenced by Plato's dialogues. Yet, in ancient Greece and in the Middle Ages, dialogue primarily refers to a literary form: instead of a meeting of subjective perspectives that evolve. Why then the term neo-Socratic, one may wonder? To address this, I will point out some important resemblances and differences between Plato's work and Socratic education.

When it comes to the antique Socratic dialogue as popularized by Plato, dialogue is a written account and therefore, a form of art that describes a discursive meeting between two or more persons who, in most cases, collaboratively and critically reason about a given subject or philosophical problem in order to arrive at a universal truth-e.g. the Symposium-or a righteous conclusione.g. Euthyphro-(Raupach-Strey, 2012).

The foundation of this inquiry is reason, according to RaupachStrey (2012) negatively delineated in Plato's dialogues as follows:

1. One should not follow opinions of the general people. If needed, only the opinions of experts.

2. One should not follow one's own emotions.

3. One should not consider the potential negative consequences for oneself to be a decisive factor.

Whoever follows the principle of Logos-i.e. understanding-as opposed to the rhetorical method or tricks of the sophists, attempts to arrive at a truth that reasonably follows from one's own insight. This is famously referred to as the maieutic approach in Theaitetos, where Socrates states that he is the son of a midwife-phaenareteand explains why he practices the same profession, only as a philosophical variant.

In addition, it is historically known that Socrates is a person who converses with everybody, making dialogue the most natural form to his character. Platonic dialogue as a quest for insight is a way of collaboratively practicing philosophy by means of critically questioning and answering. During this process of questioning and answering, ideas are tested from different perspectives and attempted to be refuted. (Sluiter, 2014)

Furthermore, dialogue in Plato's tradition embodies a certain didactic process from the perspective of both the teacher and the pupil. Strictly speaking, both participants of the dialogue depart 
from the idea of equality, whereby every step is taken in agreement. In practice, however, the teacher-Socrates-usually asks the questions and the pupil-his interlocutor-is the one who answers. The learning process of the pupil is tied to the idea that our soul has knowledge from before our birth; knowledge that has been temporarily forgotten as a result of the traumatic event of birth. In a sense then, the learning process revolves around rememberinganamnesis-what one already knows with help of the teacher who asks questions.

Critically important to educational contexts, is the fact that Plato's dialogues embody a normative idea of philosophy as an act that requires to be practiced socially. Sometimes, especially when Socrates speaks to certain sophists, he repeatedly insists that they should refrain from engaging in long monologues, and encourages them to go along with his question-answer model. When this fails, however, Socrates will eventually hold a monologue himself. In such cases, he poses a question and answers it as well (e.g. Gorgias)-a strategy that is generally avoided in today's philosophical educational practices, because it prevents the participants to philosophize themselves.

In other occasions, Plato's dialogue ends up not being a dialogue at all but instead a narration, as in the case of the Phaedo. Finally, it can be generally said that Socrates assumes a certain direction in his style of questioning. Answers to his questions are often in the form of "yes," "indeed," or "exactly!" This is very important to the dialogic process, as one has to agree on a certain conception to be able to advance together (Raupach-Strey, 2012). What one learns from a Socratic dialogue would not be possible without the idea of a collective effort driven by rational deliberation, where agreement of all parties is sought with respect to what stands up to the objections raised, and what does not.

It is in this sense that Socratic dialogue in the neo-Socratic paradigm strives for consensus. This consensus presupposes reasonable equivalence among the participants and equality of treatment by the moderator. When it comes to consensus it is important to note that it is not the same as reaching a compromise; the idea of seeking consensus serves as a motivation to expose objections-however absurd they may seem-to serious scrutiny in pursuit of new insight. (Raupach-Strey, 2012) 
Often, consensus is seen as a way of compromising, as if participating in a dialogue presupposes antagonizing others. From this perspective, consensus assumes disagreement, friction and quarrel, that should be transcended by striving for consensus. The question is whether this consensus is justly presupposed. Perhaps it is not necessary at all to strive for consensus in this sense, since the dialogue does not typically depart from this presupposition of disagreement. It starts from the shared Socratic "I know that I don't know" disposition-a disposition that already presupposes a certain consensus.

Another objection to the idea of consensus is that it presupposes an irrefutable idea as outcome, that can only count on consensus of participants because it is true. Realistically, this is hardly ever achieved. But what is more important about this presupposition is that it allows for equality of the participants as reasonable beings. Consensus, however, is not necessarily a goal in itself, it is a consequence of accepting the idea that there is a certain truth that all can equally access with the help of reason. The question is not so much whether there is one truth or not, it is the practical implication of the presupposition that matters.

Therefore, it can be said that one who only participates in a dialogue to develop one's own thoughts and insights, and is not concerned at all with collaboratively investigating a certain philosophical issue from the premise that we are all living beings with experiences and thoughts about the subject in question, is not really engaging in a philosophical dialogue. Consensus is important in as far as this togetherness is important; on the one hand consensus is something that we strive for as an outcome, on the other, consensus is what makes collaborative effort possible. Seen from this perspective, consensus is a kind of shared responsibility that all participants carry in order to facilitate the dialogic process.

The neo-Socratic tradition after Nelson \& Heckmann has much in common with the antique form of dialogue but there are important differences as well. First of all, the foundation for a theory of knowledge, as well as the conditions for it to develop, are different. Plato's Socrates held a different perspective on the possibility for objective and universal truth than Nelson did, who stood in a neoKantian tradition that problematized this perspective by offering a representationalist framework from which to think about the world. 
Another difference is found in the number of participants. In contrast to Socrates, who would usually have one interlocutor, the neo-Socratic paradigm allows for larger groups to take part in the dialogue. In the antique form and in addition to taking a leading position by determining the course of the dialogue with questions and other contributions, it was Socrates who would usually speak most of the time. In the new paradigm, however, the facilitator of the dialogue has a facilitating role and is required to stay on the background as much as possible. She takes responsibility for the understanding of the participants and lays out or explains the procedure of the dialogue. The other participants are equal in their role as speakers, and together they take part in the dialogic process. (Raupach-Strey, 2012)

\section{Speaking and listening}

So far, it may seem that speaking is at the heart of Socratic dialogue. Contrary to what one may assume, however, I will argue that a Socratic dialogue typically starts with listening rather than speaking. This seems even true for Plato's dialogues. After all, Socrates is only able to point out illogical reasoning or false truths by carefully listening and subsequently responding on the basis of what his interlocutors are saying. Indeed, this principle is central to educational Socratic dialogues as well, since the main focus is on discourse, reflection, and deliberating competing ideas as opposed to a way of recitation, where teachers do most of the talking and limit themselves to asking closed questions-better known as the initiation-reply-evaluation [IRE] structure. (Mehan \& Cazden, 2015)

It is worth noting that Socratic dialogue clearly presupposes listening, yet, despite the apparent importance of listening, there is little research about its exact role and importance for educational contexts. Conversely, the importance of dialogue in education is often emphasized in debates and reports about our education system. Terms such as $21^{\text {st }}$ century skills and democratic citizenship presuppose dialogic practices (Thijs, Fisser, \& Hoeven, 2014; Ministerie van Onderwijs, Cultuur en Wetenschap, 2017) Moreover, classroom dialogue is often seen as of intrinsic educational importance (Veen, Kruistum, \& Michaels, 2015; Veen, Mey, Kruistum, \& Oers, 2017). Strikingly, however, our understanding of Socratic education is still rather limited, resulting in a bias that 
philosophical dialogue is mainly about speaking, sharing opinions, or debating others. (Fiumara, 1990)

To arrive at a more balanced understanding of what exactly philosophical education is calling for, this paper conceptualizes dialogic listening as an undervalued yet critically important virtue, relevant to all participants of the Socratic dialogue. In addition, I understand dialogic listening as a key skill needed to attain quality and depth in educational philosophical dialogues in primary school classrooms, that may be improved with the help of music.

Finally, listening well to each other is not only essential to the quality and depth of the philosophical dialogue but for inclusive education too (Kim, 2016). Although not directly the subject of this paper, dialogic listening may also serve as an antidote to increasing threats of cultural polarization and political intolerance.

\section{The Socratic dialogue and the role of listening}

In arriving at the pedagogical principles for his method, Nelson studies both Socrates' virtues and his mistakes. One of the most important lessons he takes from Socrates is locating the "art of forcing minds to freedom" (Nelson, 1949, p. 29)-where freedom refers to liberating one's own thinking from any kind of dogmatism. To allow his pupils to do their own thinking, this also applies to the facilitator of the dialogue. After all, offering ready-made judgments or expert opinions systematically obstructs the philosophical endeavour as conceptualized by Nelson, and later, by his student Gustav Heckmann (1993). This principle also applies to the ways in which philosophical dialogue is understood in the works of such educators as Ekkehard Martens (2000) and Gisela Raupach-Strey (2012) within the continental tradition, and Matthew Lipman (2003), Ann Sharp (1992) and Gareth Matthews (1984) within the analytic tradition.

To safeguard against self-deception, Nelson (1949) elaborates, it is important that the dialogue is seen as a collective effort directed at the growth of philosophical comprehension. Clearly, in order to successfully implement this collective effort, participants need to carefully listen to each other.

According to composer Philip Glass, "the problem with listening is, of course, that we don't” (1999). Glass is specifically referring to 
our internal environment, or the structure of our thinking as he conceives of it, which according to him is not conducive to listening. However, it seems that his diagnosis applies to our external environment just as much, even increasingly so, as evident by the rising amount of screens in both the private and the public sphereincluding schools. In other words, there is little doubt about the fact that we live in a predominantly visual culture. This is not to say that there is nothing to hear; we live in a very noisy culture as well.

Hearing, however, is not the same as listening. An important difference is that listening in the context of a Socratic dialogue presupposes the acknowledgement of and engagement with what is being said-both pre-conditions for the co-creation of meaning as one of the central objectives of the Socratic endeavour. Even more rudimental, listening requires a certain willingness to acknowledge and engage in the first place. This is not essential to hearing as an act of passively registering sounds.

Interestingly, pioneering facilitators of philosophical dialogues in Japan, (Kono, Murase, Terada \& Tsuchiya, 2017), as one of the few, more or less directly stress the importance of listening with their slogan Slow Thinking. This means that participants should not rush to conclusions but instead examine questions, common sense notions, and their own assumptions. Participants of their community of inquiry therefore have three basic rights: 1) the right to ponder in silence, 2) the right not to talk when one does not want to, and 3) the right to say "I don't know" when one does not know what to say at a particular moment in the dialogue.

Would a facilitator of Socratic dialogues ignore the importance of listening inherent to the dialogic practice, participants would likely end up having an exchange of opinions that may seem very animated and engaging, but has little to do with practicing philosophy. After all, one of the differences between an exchange of opinions and a philosophical dialogue is that it is not strictly necessary to listen in an exchange of opinions; opinions are just opinions and one does not necessarily need to respond to other opinions; one can simply hear and accept that someone else has another opinion and move on. In everyday instances, this may not always be problematic but when striving for philosophical comprehension, not listening becomes an important impediment. 
I therefore argue that listening is what makes a dialogue Socratic. Certainly, if no one is speaking then there is nothing to actually listen to. But in the context of a Socratic dialogue, speaking without listening seems tantamount to not speaking at all-precisely because listening is what precedes the co-creation of meaning. This is why I refer to listening as a pre-condition, not merely a condition. It is the first condition that has to be met in order for the process of co-creating meaning to unfold.

\section{Listening to music and the philosophy of dialogue}

In a response to our mechanical ways of socializing-which have become more mechanical than ever after the introduction of social media-Elias Canetti suggests that music may become an important source of philosophical life (as cited in: Fiumara, 1990). After all, "one does not need to draw on music for it is always within us; all we have to do is listen simply, otherwise we would learn in vain" (as cited in Fiumara, 1990, p. 78).

When it comes to the distinction between listening and hearing in the educational Socratic dialogue, it is interesting to observe that meaningfully engaging with music also presupposes listening to it, not merely hearing it. Apart from the advantage of music as a source of philosophical life according to Canetti, another advantage of focusing on music in this case would be that it allows us to more or less isolate the variable listening as a skill to better understand and subsequently improve. After all, as opposed to participating in a philosophical dialogue, it is not necessary to speak in the literal sense when listening to music. Which does not mean that it is not necessary to respond at all to what is being heard, but this responding, or rather engaging, is only possible when a specific kind of listening has preceded it. This specific kind of listening is dialogic in nature. To explain what I mean by this, I discuss the basic principles of dialogic philosophy first.

Philosophy of dialogue as a twentieth century discipline typically refers to "a reciprocal and interpersonal middle" (Ritter, 1972, my translation), where meaning is co-created. As stated earlier, in ancient Greece and in the Middle Ages, dialogue primarily implies a literary form. There, it also refers to some kind of "speech 
of the soul with itself" (Ritter, 1972, my translation). But it is not until the nineteenth century that the term dialogue is truly shaped.

Where dialectics as a term related to communication is commonly understood as the art of conversing, dialogue refers to a process where subjective perspectives meet and evolve from the private, to the collective and general sphere. Ritter refers to this as an "Übergang zu einem höheren, den Rückblick ermöglichenden Standpunkt" (Ritter, 1972, p. 227). In other words, a move to a higher ground that enables (self-)reflection. This is the basis of all philosophical dialogue.

In the early twentieth century a new group of (religious) philosophers of dialogue emerge independently of each other-e.g. Hermann Cohen, Ferdinand Ebner, Franz Rosenzweig-of whom Martin Buber, writer of Ich und $D u$ in 1923, is arguably most famous. Indeed, according to Ritter (1972), Buber makes the most important phenomenological contribution to the understanding of the philosophy of dialogue, as a counterpart to Hegel's systematic and transcendental philosophy. This kind of philosophy especially influenced theological and pedagogic traditions, which is why Buber's most famous essay, Ich und $\mathrm{Du}$, is more often found in the theology section of libraries and bookshops than in the philosophy section. According to his translator Walter Kaufmann, however, the book will survive the anticipated death of theology for it speaks to those whose primary concern is not at all with religion, but rather with social change; in this case educational change.

But why use religious terms at all? As Kaufmann notes, secular times call for "a new language, new poets to create it, and new ears to listen to it" (as cited in Buber, 1970, p. 31). Are we there yet, one wonders? In any case, Kaufmann eloquently states: "if we shut our ears to the old prophets who still speak more or less in the old tongues [...]we shall have very little music" (p. 31). These prophets do not have to be religious in any sense. But as Kaufmann puts it, we cannot ignore past traditions if we want to arrive at this new language.

In short, this new language consists of two relationships, singled out by Buber in Ich und Du: 1) I recognize It (Es) as an object, especially of experience and use, and 2) $I$ respond with my whole being to You (1970). Interestingly, It can be human as well, 
just as much as You can be non-human. This reminds of Kant's Critique of Practical Reason (2015), where Kant argues to always treat humanity-in our own person as well as that of others-as an end also, and never only as a means. In Buber's terminology, this is one way of setting off the I-You relation from the I-It. As soon as a relationship has run its course or is permeated by means, the You becomes an object among objects (Buber, 1970). I will come back to these relations by relating them to the practice of dialogic listening.

\section{Dialogic listening}

The term dialogic listening is relatively new and originated in communication science literature. Here, it is set off from empathic listening on the one hand, which revolves around trying to experience what is at the root of someone's outward communication. In other words, when empathically listening, one attempts to deduce or guess the experience of the other's internal state. Dialogic listening, however, concentrates on the meanings that are being mutually created, requiring for dialogic listening to move beyond empathy to a focus on an interpersonal middle (Stewart, Zediker \& Witteborn, 2012). Most relevant here is the meaning of dia as between. Based on these insights, and Buber's philosophy, I now distinguish three interrelated features of dialogic listening in the context of Socratic dialogues. In the pursuit of meaningful engagement, these features relate to both the Socratic dialogue, and to the listener of music.

The first is openness, or the dissolution of restraint and cultivation of a pre-reflexive attitude. A good example of this has already been offered by Nelson, who would label dogmatic thinking as a kind of restraint or as an impediment to the art of "forcing minds to freedom"(Nelson, 1949, p. 29). In other words, dissolution of restraint may be understood as the dissolution of dogma: if one is only waiting to hear one's biases being confirmed or attacked, one is not really listening in a dialogic sense. This is what happens in discussions or debates where people try to convince others of their own opinions or convictions; there is engagement, but no engagement in a philosophical sense, and therefore, no co-created meanings are arrived at. Dialogic listening presupposes a free and open kind of listening that is characterized by not restraining itself to any dogma and a willingness to cooperate. This is what allows for philosophical wonder. 
Listening to speech is often done in a way that the listener tries to simultaneously interpret what the speaker is saying. This, to a great extent, is inevitable and even crucial to participating in a dialogue but it also means that the listener is translating what she is hearing, allowing for (dogmatic) impurities to be introduced that may result in a kind of compromise between the listener and speaker. From a philosophical perspective, this is not desirable. Especially not when the listener is particularly dominant in her interpretation, as this closed way of listening hinders the dialogue to move to a more inquisitive, cooperative and thus philosophical ground.

Here, music may prove to be especially helpful. When listening to music, one may learn to refrain from interpreting immediately and practice the cultivation of a greater kind of openness. What is especially helpful about music in this sense is that it does not allow for immediate and specific interpretations. Music is inherently abstract and does not communicate preconceived ideas in the way that speech does. Precisely this difference serves as an argument to turn to music for the practice of listening, instead of speech; music allows for more openness because it is not immediately interpretable in the same way a spoken phrase is. What is more, it does not even require to be interpreted in the first place, allowing for the cultivation of a pre-reflexive and non-dogmatic kind of listening. In one of his lectures discussing music as an example, Merleau-Ponty put it as follows: "All I have to do here is listen without soul-searching, ignoring my memories and feelings and indeed the composer of the work, to listen just as perception looks at the things themselves." (as cited in Szyszkowska, 2018, p. 145).

The second feature is reciprocity. The dialogic is a fundamental behavioural attitude that becomes active in relation to voice, including non-human voices. This is important, since it is precisely the feature that makes it possible to speak of dialogic listening in the context of music. Put differently, this suggests that a work of art can be a You as well. What is more, it should be recognized as a You if one is to enter into a dialogic relation with it, meaning that the work of art is not primarily an object to be put to use, or an object of experience: it is the voice of You speaking to me, requiring a response. (Buber, 1970)

In both Socratic dialogue and in the case of music, the relation between $I$ and You becomes reciprocal by allowing You to speak 
through the effort of listening. Dialogic listening in this sense is an active and receptive quality by virtue of enabling the other to speak. In the case of another person this is more or less obvious but in the case of music, reciprocity amounts to an attitude of opening up to music in a way that it has something to tell, as opposed to something entertaining, or something to enjoy on the background.

The third feature is awareness, or the process of becoming aware of the other. This refers to taking the other-whether a person or a work of art-in its totality as opposed to a set of abstractions. In the case of another person, one would fail to take a person as a whole when perceiving the other only as a member of a certain race, culture, gender, socio-economic background or political orientation, for example. This part of the cooperative effort starts with dialogically listening to the totality of the You as a voice requiring a response. (Buber, 1970)

This is true for music as well; whoever is only waiting for a certain Leitmotiv in a Wagner opera to return, or only listens to the percussive movement of Shostakovich' seventh symphony is not really engaging with the piece of music as a whole. Nor is one who only listens to music that "adapts itself to the wishes of the listener", as Elmer Schönberger put it in his lecture Het Grote Luisteren (2007).

In order to further understand this feature in the context of music, it is helpful to look at some of Gadamer's ideas on aesthetics. In Truth and Method (2013), Gadamer argues against the principle of aesthetic differentiation (ästhetische Unterscheidung). This principle assumes that the aesthetic quality of a work of art should be distinguished from its content-specific properties. A piece of music, for example, is not judged on its aesthetic quality by looking at the notes that are written in the music sheet. In Buberian terms we would turn the music into an It that way, preventing us to engage in any sort of dialogic relation.

Instead, Gadamer offers the principle of ästhetische Nichtunterscheidung, or aesthetic non-differentiation, which means that the aesthetic quality of a work of art cannot be isolated from the work itself (Gadamer, 2013). The work of art does not consist of properties or tones, in the case of music; it expresses something unique as a work of art in its totality and in its situatedness in the 
world. This means that art never wholly speaks for itself; it always requires some sort of activity from the one engaging with it. What is more, the work of art does not exist outside of the aesthetic experience according to Gadamer; the identity of a work of art is established by engaging with it. In dialogic terms one may refer to this hermeneutic identity as the voice of art or the inner life of a composition whose meaning is not waiting to be discovered, but is co-constructed in a dialogic relation.

The fact that there is something to be interpreted in the first place-and more importantly, that it wants to be interpreted-is what makes this identity hermeneutic. Put in Buberian terms, music speaks to us as a You to an $I$ in its totality, not merely to an $I$ as a concert visitor or a middle-class person with a certain cultural background, for example. Gadamer sees this quality as a demand from the work of art that is waiting to be redeemed. The work of art demands some kind of answer, which can only be provided by the $I$ that relates to the work of art as a You-see previous feature. This is not a universal answer, but an answer given by the $I$ that enters into a dialogue with the work of art. Again, the piece of music and its meaning are not embedded in the work itself, but in the relation with its listener-which explains why every You is different for every $I$.

The same is true for the participants of the Socratic dialogue. Just as a piece of music does not consist of tones, a person does not consist of personal characteristics and properties. Both express something unique in their totality, which can only become meaningful in a dialogic process enabled by listening.

\section{Conclusion}

According to Buber (1970), real dialogue has become a rarity. Most of what people do when conversing should be referred to more accurately as chatter-nowadays in the figurative and literal sense. Although it may seem so, people do not really engage in dialogue with each other by listening, but rather by (online) chatting and hearing. If this is true, and taking the isolating effects of social media into account (Twenge, 2017), Buber is more right than ever today.

The same applies to people's engagement with music. Although there has never been more music in the private and public space, music in most cases has been degraded to the background and 
more often than not, serves as a means to a-commercial-end. In addition, nowadays it seems to have become normal to wear earphones or headphones whilst chatting to other people. However, simultaneously hearing music and hearing other people talk causes us to hear a lot, but prevents us from listening to anything at all.

These social problems revolving around listening are clearly not favourable to the quality of the Socratic dialogue. With the help of the cultivation of dialogic listening, however, this pattern of behaviour may change. Dialogic listening does not mean listening to as many people or as much music as possible. As a precondition for co-created meanings, it denotes an activity where 1) openness, 2) reciprocity, and 3) awareness are of pivotal importance. Buber emphasizes repeatedly that the key to a dialogic relation is to treat the other-person or music-not as an object, but as a You, and as a consequence, a partner in life. It is true that this is sometimes difficult and requires an effort. What is more, listening "demands a strength and rigour that are difficult to subjugate and that deserve constant exercise" (Fiumara, 1990, p. 60). But it is an exercise and effort worth making, because it allows for meaningful and philosophical relations to both people and art.

Although music does not require discursive interaction in the same way as the participant in a dialogue, it does require, or even demand, some sort of response in order to speak of a meaningful engagement. Music never wholly speaks for itself, nor does any given statement in a dialogue; in order for their voices to become potential contributors to the "sculpting of mutual meanings" (Stewart et al., 2012, p. 202), they both require a listening subject that engages with them dialogically. As De Munck (2014) put it, musical engagement should not be understood as the product or effect of the musical experience, nor as the content of music itself. Indeed, it is the meaningfulness of the musical engagement that is implied in the listening practice itself, just as the meaningfulness of the philosophical engagement is implied in the listening practice during a Socratic dialogue.

Listening to music is not meant to be understood as a mere metaphor for the importance of listening here, but as a complementary opportunity to the philosophical educational practice. Although this paper is not conclusive in completing the argument that listening to music actually improves philosophical listening in educational 
practices, it attempts to show that the metaphor is apt enough to suggest that it captures something essential in our thinking about the educational philosophical endeavour. Further research is needed to gain a more profound understanding of what it means to listen, and whether listening to music is dialogic enough to make the case for a more musical philosophical practice. One possibility to take further steps in this area involves embedding these questions in a phenomenological framework. After all, similar to the attitude that is sought after in the practice of philosophical dialogue,

phenomenology is one attempt to step back from certain types of involvement with the world and direct our attention to specific features of our experience of the world. Herein lies the clue to the epoché and the direction of phenomenological description. (Ihde, 2007, p. 204)

Indeed, the interest for concreteness of experience in phenomenology seems to make perfect sense for addressing questions within the philosophical educational practice.

Listening to music-following further scrutiny-may ultimately come to be understood as a philosophical activity to the extent that it allows for a dialogic practice, facilitating the process of new meaning, co-created between I-the listener-and You-the piece of music and interlocutor. Precisely this practice and longing for meaning is the point of departure in the true sense of philosophy. It is in this sense that listening to music may help us become better philosophers.

\section{References}

Buber, M. (1970). I and Thou (W. Kaufman, Trans.). Edinburgh: T. \& T. Clark. (Original work published 1923).

Fiumara, G. (1990). The Other Side of Language: A Philosophy of Listening. New York: Routledge.

Gadamer, H. (2013). Truth and Method (J. Weinsheimer \& D. G. Marshall, Trans.). London: Bloomsbury. (Original work published 1975).

Glass, P. (1999). Listening to Philip Glass. Retrieved from: https://tricycle. org/magazine/listening-philip-glass/

Heckmann, G. (1993). Das Sokratische Gespräch. Erfahrungen in philosophischen Hochschulseminaren. Frankfurt am Main: Philosophisch-Politischen Akademie. 
Ihde, D. (2007). Listening and voice: phenomenologies of sound. Albany: State University of New York press.

Kant, I. (2015). Critique of Practical Reason (M. Gregor, Trans.). Cambridge: Cambridge University Press. (Original work published 1788).

Kim, M. (2016). Was macht Kinder tolerant? Zeitschrift für Didaktik der Philosophie und Ethik, (2), 46-55.

Kono, T., Murase, T., Terada, T., \& Tsuchiya, Y. (2017). Recent Development of Philosophical Practice in Japan. Journal of the APPA, 12(2), 19351946.

Lipman, M. (2003). Thinking in Education. New York: Cambridge University Press.

Martens, E. (2000). Spelen met denken. Over filosoferen met kinderen (I. van der Aart, Trans.). Rotterdam: Lemniscaat. (Original work published 1999).

Matthews, G. (1984). Dialogues with Children. Cambridge: Harvard University Press.

Mehan, H., \& Cazden, C. (2015). The Study of Classroom Discourse: Early History and Current Developments. In L. Resnick, C. Asterhan, \& S. Clarke. (Eds.), Socializing Intelligence Through Academic Talk and Dialogue. (pp. 13-34). https://doi.org/10.3102/978-0-935302-431_2

Ministerie van onderwijs, cultuur en wetenschap. Inspectie van het onderwijs. (2017). Burgerschap op school. Een beschrijving van burgerschapsonderwijs en de maatschappelijke stage. Retrieved from https://www.onderwijsinspectie.nl/documenten/ rapporten/2017/02/o7/burgerschap-op-school

Munck de, M. (2014). Muziek en mystiek. Naar een filosofie van muzikaal engagement. In Reitsma, O., van Gerwen, R., Munck de, M. (Eds.), Muziek ervaren. Essays over muziek en filosofie. 58-76. Eindhoven: Damon.

Nelson, L. (1949). Socratic method and critical philosophy. Selected essays by Leonard Nelson (Thomas K. Brown III, Trans.). London: Oxford University Press. (Original work published 1922).

Raupach-Strey, G. (2012). Sokratische Didaktik. Die didaktische Bedeutung der Sokratischen Methode in der Tradition von Leonard Nelson und Gustav Heckmann. Münster: Lit Verlag.

Ritter, J. (1972). Historisches Wörterbuch der Philosophie, 2. Band (D-F). Basel: Schwabe Verlag. 
Schinkel, A. (2017). The educational importance of deep wonder. Journal of Philosophy of Education, 51(2), 538-553. https://doi. org/10.1111/1467-9752.12233

Schinkel, A. (2018). Wonder and moral education. Educational Theory, 68(1), 31-48. https://doi.org/10.1111/edth.12287

Schönberger, E. (2007). Het gebroken oor. Amsterdam: Meulenhoff.

Sharp, A., Reed, F., \& Limpan, M. (1992). Studies in philosophy for children: Harry Stottlemeier's discovery. Philadelphia: Temple University Press.

Sluiter, I. (2014). Socrates. Elementaire Deeltjes 3. Amsterdam: Amsterdam University Press.

Stewart, J., Zediker, K., Witteborn, S. (2012). Empathic and Dialogic Listening. In Stewart, J. (Ed.), Bridges Not Walls. A book about interpersonal communication. (pp. 192-208). New York: McGrawHill.

Szyszkowska, M. (2018). Musical Phenomenology: Artistic Traditions and Everyday Experience. AVANT. The Journal of the PhilosophicalInterdisciplinary Vanguard, 9(2), 141-155. https://doi.org/10.26913/ avant.2018.02.09

Thijs, A., Fisser, P., \& Hoeven Van Der, M. (2014). 21e eeuwsevaardigheden in het curriculum van het funderend onderwijs. Enschede: SLO.

Twenge, J. (2017). Have Smartphones Destroyed a Generation? Retrieved from https://www.theatlantic.com/magazine/archive/2017/09/ has-the-smartphone-destroyed-a-generation/534198/

Veen, C., Kruistum, C., \& Michaels, S. (2015). Productive classroom dialogue as an activity of shared thinking and communicating: A commentary on Marsal. Mind, Culture, and Activity: An International Journal, 22(4), 320-325. https://doi.org/10.1080/10749039.2015.1071398

Veen, C., Mey, L., Kruistum Van, C., \& Oers, B. (2017). The effect of productive classroom talk and metacommunication on young children's oral communicative competence: An intervention study in early childhood education. Learning and Instruction, (48), 14-22. https://doi.org/10.1016/j.learninstruc.2016.06.001 